\title{
Occupational Transitions at Older Ages: What Moves are People Making?
}

Amanda Sonnega, Brooke Helppie McFall, and Robert J. Willis 


\title{
Occupational Transitions at Older Ages: What Moves are People Making?
}

\author{
Amanda Sonnega \\ University of Michigan \\ Brooke Helppie McFall \\ University of Michigan \\ Robert J. Willis \\ University of Michigan
}

September 2016

\author{
Michigan Retirement Research Center \\ University of Michigan \\ P.O. Box 1248 \\ Ann Arbor, MI 48104 \\ www.mrrc.isr.umich.edu \\ (734) 615-0422
}

\section{Acknowledgements}

The research reported herein was performed pursuant to a grant from the U.S. Social Security Administration (SSA) funded as part of the Retirement Research Consortium through the University of Michigan Retirement Research Center Award RRC08098401. The opinions and conclusions expressed are solely those of the author(s) and do not represent the opinions or policy of SSA or any agency of the federal government. Neither the United States government nor any agency thereof, nor any of their employees, makes any warranty, express or implied, or assumes any legal liability or responsibility for the accuracy, completeness, or usefulness of the contents of this report. Reference herein to any specific commercial product, process or service by trade name, trademark, manufacturer, or otherwise does not necessarily constitute or imply endorsement, recommendation or favoring by the United States government or any agency thereof.

\section{Regents of the University of Michigan}

Michael J. Behm, Grand Blanc; Mark J. Bernstein, Ann Arbor; Laurence B. Deitch, Bloomfield Hills; Shauna Ryder Diggs, Grosse Pointe; Denise Ilitch, Bingham Farms; Andrea Fischer Newman, Ann Arbor; Andrew C. Richner, Grosse Pointe Park; Katherine E. White, Ann Arbor; Mark S. Schlissel, ex officio 


\title{
Occupational Transitions at Older Ages: What Moves are People Making?
}

\begin{abstract}
Given the clear benefit for both public and private finances of extending work lives, many policymakers are interested in finding and promoting ways to accomplish this objective while balancing concerns for work ability at older ages. At the same time, retirement itself is transforming from a simple transition from full-time work to full and permanent retirement to more of a process, potentially occurring in several stages over a number of years. We consider a set of work transitions at ages when the largest numbers of people are retiring and potentially pursuing different paths to full and permanent retirement. Among workers who transition between occupations, the most common transitions are between those that are closely related. However, even within closely related occupations, there are no large pipelines between any two. By age 62, 57 percent of workers are no longer in the labor force, 26 percent are still in their "career" occupation, and 17 percent have changed from their career occupation to another occupation. Beginning at age 66, however, the percentages in different occupations, which may be bridge employment or unretirement, are very similar to the percentages remaining in career occupations. Occupational changes later in life tend to be accompanied by decreases in hourly earnings, suggesting that if workers are seeking flexible or part-time bridge employment, it may come at a cost.
\end{abstract}

\section{Citation}

Sonnega, Amanda, Brooke Helppie McFall, and Robert J. Willis. 2016. “Occupational Transitions at Older Ages: What Moves are People Making?” Ann Arbor, MI. University of Michigan Retirement Research Center (MRRC) Working Paper, WP 2016-352. http://www.mrrc.isr.umich.edu/publications/papers/pdf/wp352.pdf

\section{Authors' acknowledgements}

The research reported herein was pursuant to a grant from the U.S. Social Security Administration (SSA), funded as part of the Retirement Research Consortium (RRC). The findings and conclusions expressed are solely those of the authors and do not represent the views of SSA, any agency of the federal government, or the University of Michigan. The authors are very grateful to Orla Hayden (RAND) who provided technical assistance and support and to Adam Karabatakis for excellent research assistance. 


\section{Introduction}

Given the clear benefit for both public and private finances of extending work lives, many policymakers are interested in finding and promoting ways to accomplish this objective while balancing concerns for work ability at older ages. For some individuals, staying on the job longer has benefits beyond just the financial, such as maintaining cognitive and physical health (Rohwedder and Willis, 2010; Insler, 2014). Other evidence suggests that some workers stay on the job despite having health problems to offset diminished wealth accumulation resulting from poor health (Bound, Stinebrickner, and Waidman, 2010). Thus, an important societal goal, and the main thrust of much public retirement and disability policy, is to foster employment opportunities for older workers while at the same time affording reasonable paths to exit the labor force for those who are unable to work.

As younger cohorts are beginning to work to older ages, it seems clear that they are responding to public and private sector changes that encourage longer work while also charting their own paths that may reflect personal preferences, for example, to have part-time and/or more flexible work schedules. In the private sector, the shift from employer-sponsored defined benefit (DB) to defined contribution (DC) pension plans and reductions in retiree health insurance coverage have tended to discourage earlier retirement (Hurd and Rohwedder, 2011; Mermin, Johnson, and Murphy, 2007). Public policies, such as the abolition of mandatory retirement, the gradual increase in the eligibility age for full Social Security benefits, the removal of the earnings test, and the increase in the delayed retirement credit, have tended to increase incentives for older workers to stay on the job (Gustman and Steinmeier, 2015) while the availability of Social Security Disability Insurance continues to provide retirement paths for workers with work-limiting health problems. 
At the same time, retirement itself is transforming from a simple transition from full-time work to full and permanent retirement to more of a process that occurs in stages over a number of years. Research demonstrates multiple retirement paths such as those leading from full-time to part-time work to full retirement, a so-called phased retirement (Cahill, Giandrea, and Quinn, 2014). Others go from a full-time career job to another, shorter duration job to full retirement (Cahill, Giandrea, and Quinn, 2015). These intermediate jobs are often referred to as 'bridge jobs.' Other research reveals a pattern of 'unretirement,' in which workers retire completely from full-time work and, after a period out of the workforce, return to either full- or part-time work (Maestas, 2010). While this trend to a more dynamic career denouement is surely influenced by formal workplace policies (and other external constraints), it also seems likely that in our modern “do-it-yourself” retirement landscape (as Cahill, Giandrea, and Quinn, 2015 refer to it), workers are asserting their agency by making decisions about work that we are only just beginning to understand.

As policymakers continue working to develop salutary retirement policy in this dynamic environment, it is important to continue to update our understanding of how older workers are responding to policy and are themselves trying to create work situations that reflect their changing needs and desires as they eventually move to full and permanent retirement. Thus researchers are increasingly trying to understand more about who takes what paths to retirement and what constraints older workers may face as they attempt these paths.

Two decades of research have yielded important information. Many studies use the rich data resources of the Health and Retirement Study (HRS) to investigate retirement transitions. As a whole, the literature supports the finding that transitional retirements are increasingly the norm: Younger generations are not only working longer, but they are much less likely to move from 
full-time employment to full and permanent retirement. Johnson, Butrica, and Mommaerts (2010) show that 50 percent of men born 1913 to 1917 followed the traditional retirement path from full employment to full retirement, but only 34 percent of men who were born two decades later followed this path. Interestingly, Maestas (2010) shows that unretirement is often anticipated and even part of an individual's retirement plans. For the HRS cohort, born 1931 to 1941, only 8 percent of those who say they had not expected to return to work actually ended up returning to work. Workers in this cohort are more likely to return to part-time work than fulltime, especially if they are eligible for full Social Security retirement benefits.

The trend is continuing in later birth cohorts as well. Early Baby Boomers, especially women, are more likely than those in earlier cohorts to move to a bridge job before retiring. Both men and women in this cohort are also more likely than earlier cohorts to leave the workforce involuntarily through layoffs (Cahill et al., 2015). Younger workers in good health are the most likely to return to work after retiring (Cahill et al., 2011). Wang et al. (2008) use the first three waves of the HRS to study transitions to bridge employment over time. Those who are younger, in better health, more educated, less stressed at work, and more satisfied by their job are more likely to move to bridge employment in their career jobs than to retire.

Retirement transitions differ for men and women. Kail and Warner (2013) show that among those who return to work after retirement, men are more likely than women to return to full-time work whereas women are more likely to return to part-time work. Pleau (2010) finds that 43 percent of female retirees are re-employed following retirement compared with 50 percent of retired men in the HRS cohort. While women with higher earnings before retirement are more likely to return to work, wealth and earnings are negatively associated with reemployment for men. Marital status affects these findings. Married women with higher 
household wealth are less likely to be employed after retirement compared to married women with less wealth. Divorced and separated women have a greater likelihood of post-retirement employment than married women.

Other research addresses job characteristics of jobs held by older workers, finding a striking decrease in the physical demands but an increase in the perceived stressfulness of jobs over the past 25 years (Johnson, 2004). Johnson, Mermin, and Ressenger (2007) report that in 2006 almost half of older workers held jobs that involved at least some stress. Thus, they note that while older workers may be increasingly likely to meet the physical demands of their jobs, they may not be willing to stay in stressful jobs if they can afford to retire. The cognitive demands of jobs have also been increasing, which could disadvantage older workers as employers are less likely to invest in the training needed to keep older workers up-to-date on technological change. Nonetheless, on balance, they suggest that changes in the nature of work should represent significant opportunities to keep older workers on the job.

As workers seek paths to retirement, the option to reduce hours on the career job may be a very appealing option for many workers, allowing them to continue doing the work they have invested in while potentially avoiding higher stress and giving them flexibility to begin enjoying more leisure time or to care for family members. Cahill, Giandrea, and Quinn (2015) use HRS data to compare the availability of work hours flexibility to their actual use. They find that the availability of work hours flexibility is relatively low, around 25 percent, and over the course of study, only 10 percent actually do reduce hours on a career job. This implies workers must change jobs (and perhaps occupations) if they want work hours flexibility.

To our knowledge only one other report has used the detailed (three-digit census code) occupational data in HRS to study occupational changes toward the end of working life. Johnson 
and Kawachi (2007) select a sample of workers in the HRS who changed jobs between the ages of 45 and 75 over the period 1986 to 2004 to study what effects later life job changes have on wages, benefits, and other indicators of job quality. While HRS enrolls eligible respondents at age 51 and older, the baseline job history information allows them to go back six years prior to entry into the study (from 1986 for those entering in 1992, from 1992 for those entering 1998, and from 1998 for those entering in 2004). They examine how wages, industry, and occupation changes when these workers change jobs due to retirement, layoff, voluntarily leaving, and other reasons. Overall, hourly wages fell by a few dollars when older workers changed jobs. Older job changers leaving long-term employment (jobs held for more than 10 years) tended to move out of managerial occupations and into sales and service occupations. Only about 23 percent of older job changers who left long-term employers remained in the same detailed occupation category on their new job. Although this study utilized the detailed occupations to examine shares of workers making transitions between occupations, they do not report on these changes at the detailed level.

Another way to gain insight on later-life work transitions is to simply observe the occupations in which these transitions may be occurring. To that end, this paper uses data from the Health and Retirement Study (HRS) to examine occupational and labor force transitions at the detailed level toward the end of working life. While there are a number of datasets that could be used to observe occupational transitions, the HRS has the additional value of rich measurement of a wide range of potentially important explanatory factors, as well as long-term longitudinal follow-up of respondents that will allow us in the future to characterize the kinds of transitions being made. In the present work, we examine occupational transitions at the detailed 
level and characterize moves in terms of earnings across several types of occupational transitions over varying amounts of time.

\section{Prior Work}

In our prior work with HRS detailed occupational data, we have found interesting differences in which occupations are likely to be associated with longer work lives and earlier workforce departure (McFall, Sonnega, Willis and Hudomiet, 2015). While prior research using aggregated occupational categories shows that, in general, white collar occupations are likely to stay longer in the work force, while blue collar workers tend to leave earlier, our findings suggest some interesting departures. As would be expected, we find white collar, especially creative or labor-of-love-type jobs such as clergy or writers/authors and/or those that are not physically demanding, common in longer working occupations. However, we also find occupations such as taxi drivers and chauffeurs, guards and watchmen, and messengers as jobs where people are working past age 66. In regressions with binary indicators for each detailed occupation on indicators of working past age 63 and past age 66, we find that many more occupations are associated with earlier workforce departure than longer work, suggesting that increased attention be paid to identifying characteristics of occupations that encourage earlier retirement rather than just longer work.

Thus our prior work begins to shed light on the types of occupations in which workers stay in the labor force longer versus depart earlier. The present work aims to understand more about later-life transitions between occupations that may reveal something about the options faced by workers who would like to work longer. We consider a set of work transitions at ages when the largest numbers of people are retiring and potentially pursuing different paths to full and permanent retirement. 


\section{Data and Methodology}

The HRS is a longitudinal biennial survey of adults in the United States that is nationally representative of the population older than 50. We use HRS data on job history and the detailed occupation of jobs held by HRS respondents across 10 biennial waves of data collection between 1992 and 2010. We use information from the core interview on education and employment information, including labor force status and earnings. We use constructed variables from the RAND-HRS version O (Chien et al., 2015) for all but the occupation variables. Only masked (highly aggregated) occupational data are available in the public release version, and the detailed data that we use are available under restricted conditions.

\section{Measures}

Occupation. In the employment section of the interview, the HRS asks of all currently and formerly employed individuals, "What sort of work do (did) you do?”; and in later waves additionally, "What is (was) your title?” The HRS uses information from these questions to apply U.S. Census occupation codes for the current job, a past job held since the most recent HRS interview, or a job reported in the baseline job history data. Because the census occupational codes have changed over time, the occupational coding schemes in the HRS data have changed as well (Nolte, Turf, and Servais, 2014). We use a coding scheme (available here) that attempts to match the HRS detailed occupational codes used from 1992 to 2004 with those from later years. The scheme also aggregates across small, similar occupation groups so that each occupational category holds at least 100 respondents across all waves in as many of the categories as feasible while grouping similar occupations. Due to difficulties adapting our occupation coding scheme to an updated set of Census 2010 codes used for the 2012 HRS occupational data, we exclude data from 2012 in the current version of this paper. 
The resulting coding scheme contains 192 separate occupations or occupational groups. Twenty-two of these categories are "other" categories, e.g., other financial specialists, other managers, other health and therapy occupations, etc. It is important to note that these categories are usually collections of occupations that are less closely related and less consistent over the years than the remaining categories. For example, they contain some occupations that were part of the 1980 coding scheme, but had been dropped by the 2000 scheme or that emerged for the first time in 2000, as well as groupings of smaller occupations that are not closely related.

Occupation of longest held job. Due to the complex flow through the employment section of the HRS interview and inconsistencies over time in how the employment variables are collected, it is a major task to create a variable that reflects the tenure in the longest held job over the full length of the survey. The RAND version of the HRS contains this variable for each wave and an associated variable for the occupation in the longest held job. Since it is part of the public release data, however, it is only reported for the masked version of the detailed data. We obtained the SAS code from RAND and used our detailed occupation data (using the 192 crosswave consistent occupational codes) as the input dataset to obtain a detailed occupation version of the RAND variable for occupation in the longest held job.

Hourly earnings. We used hourly earnings from the longest held and the current job at each wave. Values are adjusted for inflation using the consumer price index (CPI) to 2016 dollars.

Labor force outcomes. RAND creates a variable that summarizes labor force status at each wave $(R w L B R F)$ as working full-time (35+ hours/week and 36+ weeks/year), working parttime, unemployed (not working but looking for a job), partly retired (working part-time and 
mentions that he/she is retired), retired, disabled, or not in the labor force. We used this variable to create various labor force statuses and status transitions.

\section{Analysis Plan}

In the first stage of our work, we construct a person-wave data file (long) to describe the most common detailed occupations in the HRS and common occupational transitions between consecutive waves across the period 1992 to 2010, for workers 55 and older. These results are reported in Tables 1-3. Next, we utilize a person-level (wide) dataset to examine transitions from the occupation in the longest held job as of age 55 to occupational status at ages 62, 66, 68, and 70. The occupational status outcomes we consider in the second period are: not in the labor force, in the same occupation, and in a different occupation (Table 4). If in a different occupation, we examine which occupation this is (Table 5). For those whose occupation in the current job at age $62,66,68$, or 70 is a different occupation from the longest-held job, we examine the change in hourly earnings to shed some light on whether the job is likely a betterpaid promotion, a lateral move, or a lower-paid bridge or part-time job (Table 6). Next, we use a sample of the longest-held occupations at age 55 that are particularly physically-demanding or high-stress, and characterize the occupation and earnings status at later ages (Table 7), to learn about the retirement paths of workers in these types of jobs.

We use Current Population Survey (CPS) data on education, earnings, and occupation to compare with the HRS data to confirm the representativeness of our sample of working adults. Details of our processing of these data are provided in Appendix A, and results of our comparison are in Appendix B. We used CPS surveys from January 1992 to December 2012 to roughly correspond with the HRS survey period data used. The CPS reports on the detailed census occupation codes, and we use the coding scheme described above to create the same 192 
occupational categories for comparability with HRS occupational data. We then look at population frequency, mean educational level, and mean earnings for the older workers in each of the detailed occupation categories. In short, we find evidence of reasonably similar patterns of jobs and associated levels of education and earnings in the HRS and CPS.

\section{Results}

Common occupations and associated levels of average earnings and education

Table 1 reports on the 15 most common detailed occupations among respondents 55 and older in the HRS, along with corollary average earnings and educational levels. These 15 occupations account for almost 40 percent of all occupations held by HRS respondents at the age of 55 or older. Other managers is the largest category encompassing a range of relatively highlevel managerial positions with average earnings of about \$42/hour and an educational level of 13.9 years. The highest educational levels are associated with primary and secondary school teachers and registered nurses. Educational levels align sensibly with earnings levels. (Note that in this and subsequent tables, we report “most common” occupational categories; however, results for all occupational categories are available upon request, albeit with some cells suppressed to protect confidentiality.)

\section{Transitions into occupations}

To begin our study of occupational transitions, we examine a set of labor force transitions between any two consecutive waves between 1992 and 2010, for those 55 and older, where work status goes from any other occupation at $t-1$ to the listed occupation at $t$ (Table 2a), continuous employment in the same occupation in $t-1$ and $t$ (Table $2 \mathrm{~b}$ ), from being out of the labor force at $t$ 1 to being in the listed occupation at $t$ (Table 2c), and from being unemployed in $t-1$ to in the occupation at $t$ (Table 2d). Each of the tables is sorted by the percentage (highest to lowest) of 
observations in each of these transitions. For brevity, we display only the top 15 most common transitions.

Table 2a shows common occupations that HRS workers transition into from other occupations. For example, among workers 55 and older who were managers of properties and real estate at wave $t, 50.3$ percent were in a different occupation at $t-1$. Occupations in this table may be those with relatively low barriers to entry at older ages or may represent transitions from other closely related occupations. Some of these occupations appear to involve seasonal work, such as carpenters, or timber, logging, and forestry workers, or painters, construction, and maintenance. They may also be high turnover occupations, such as customer service reps and investigators and adjusters.

Table $2 \mathrm{~b}$ shows common occupations where we see the greatest persistence from wave to wave. For example, 82 percent of secondary school teachers were in the same occupation in the previous wave. It is important to note that many of the most highly specialized occupations (such as judges, physicians, and dentists) were excluded from inclusion in this table due to smaller cell sizes that risk confidentiality. The remaining occupations presented are fairly disparate. They represent careers, such as life scientists, primary school teachers and secondary school teachers. Other occupations may be unionized work. Several of these occupations could be categorized as not very physically demanding such as office supervisors, teacher assistants, secretaries, stenographers, and typists, and therefore easier to remain in as people age.

In Table 2c, which is sorted by the percentage entering the labor force after being out of the labor force in the previous wave, we see occupations that are likely representing unretirements, that is, people who had considered themselves out of the labor force and then returned to work.percentages here range from about 22 percent to 11 percent of older workers in 
these occupations who are entering the labor force into these occupations. Here we find occupational categories that tend to reflect mostly lower skill, part-time, or flexible occupations, with low barriers to entry (e.g., child care workers, taxi cab drivers and chauffeurs, food prep workers etc.). It is somewhat surprising to see evidence of unretirements in occupations that would appear to be quite physically demanding.

Table $2 \mathrm{~d}$ is sorted by the percentage of those who reported themselves in the labor force but not working (likely unemployed) or those who were on temporary leave or disability. The percentages in this table are much lower given that many fewer older workers in general find themselves unemployed or on temporary leave. Not surprisingly, these occupations tend to be seasonal or relatively low-skill.

In Table 3, we zero in on the most common occupation-to-occupation transitions between consecutive waves (from 1992 to 2010) among workers 55 and older. In this table, we exclude the "other" occupational categories and cases where "not in the labor force" was the work status at either wave. All of these transitions reflect moves between closely related occupational categories with no surprising “pipelines” between less related occupational groups. We see some instances of moves “up” within an occupational field, such as carpenters to supervisors of construction work, and farm occupations, except managerial to farm operators and managers. More prevalent, however, appear to be moves “down,” perhaps as workers begin to step back as they move toward retirement, for example, from mathematical and computer scientists to computer programmers, support specialists, and administrators or office supervisors to secretaries, stenographers, and typists. As a side note, our comparison to the CPS revealed a reasonable amount of overlap in these specific transitions. 
Transition from occupation of longest held occupation at age 55 to occupation at ages 62, 66, 68 , and 70

The first three tables considered movement between occupations in consecutive waves of the HRS. We now turn to considering transitions from career work to various labor force status changes, including labor force exit (includes retirement, disability, and out of the labor force based on the RAND variable $R w L B R F)$, continued employment in the same occupations, and changes in occupation at a set of ages that span Social Security ages of eligibility. Looking at changes from occupation at the longest-held occupation a worker had up to the age of 55 ensures that the starting point for these analyses is the closest thing to a worker's "career" job during their prime working years. The ages at which we examine outcomes, 62, 66, 68, and 70 (or the HRS wave immediately after a respondent reached each target age), allow us to shed light on outcomes such as unretirement, bridge employment, and full retirement at the ages most relevant for the retirement and Social Security claiming processes.

In Table 4 we show that by age 62, 57 percent are no longer in the labor force, 26 percent are still in their "career" occupation (that is, longest held occupation), and 17 percent have changed from their career occupation to another occupation, potentially indicating bridge employment or unretirement. The rest of the table shows a steep labor force exit curve as expected. However, beginning at age 66, the percentages in different occupations, which may be bridge employment or unretirement are very similar to the percentages remaining in career occupations.

In Table 5, we provide a list of the most common transitions from longest held occupation at age $55(t-1)$ to a different specific occupation at ages $62,66,68$, and $70(t)$. As in Table 3, we exclude the "other" occupational categories as they tend to be not very informative. The transitions are all between closely related occupations, again with no surprising transitions 
or clear pipelines between occupations. Overall, the cell counts are low, suggesting that there is not a lot of movement between any two particular occupations at older ages. Some seem to be a step down in responsibility and may be moves to bridge employment or more flexible jobs. Several are clearly lateral moves and some are moves “up.”

In Table 6, we characterize transitions similar to those reported on in Table 4, but we provide detail on the changes in earnings associated with occupation changes. At each of the target ages we consider, the numbers of individuals whose hourly earnings decline by at least 10 percent exceed those whose hourly earnings increase by at least 10 percent for individuals who changed occupations. That is, the modal outcome for workers who are in a different occupation at $62,66,68$, or 70 than the occupation of their longest-held occupation is a move to a position with lower hourly earnings rate. Also, lateral moves in terms of earnings become less common as workers age.

Finally, Table 7 presents information about transitions from longest-held occupation as of 55 to labor force outcomes at age 66 . This is similar to the second panel of Table 6 , but is presented at the occupation level for two groups of occupations: those which involve a high degree of physical demand and those that involve a high level of stress. We selected a set of occupations involving a high degree of physical demand as those indicated by high levels of agreement with the statement "My job is physically demanding” in the HRS. We selected a set of occupations involving a high degree of stress as those indicated by high levels of agreement with the statement "My job involves a lot of stress" in the HRS. Relative to the average across all occupations, those in physically demanding career jobs were more likely to either exit the labor force or remain in the same occupation. That is, they were less likely to have changed into a different occupation by age 66. In one case, farm occupations, except managerial, a very large 
proportion of those for whom this was a career occupation appear to be unable to exit the labor force even at age 66. All other occupations characterized as physically demanding had very high levels of labor force exit by age 66. For occupations characterized as stressful, the patterns are less clear.

\section{Conclusion}

Increasingly, workers are charting a variety of paths into retirement. While some research has characterized the various paths (i.e., bridge jobs, unretirements) being taken, less is known about the specific occupational transitions workers may be making at older ages. This preliminary descriptive work uses information on the detailed occupational categories in the HRS to begin to explore this question. We first construct a set of transition matrices examining short-term, labor force status and occupational changes between HRS waves (over two years) to get a sense of common transitions for workers 55 and older. We find that the occupations workers are most likely to move into from other occupations tend to be seasonal (such as carpenters) or have low barriers to entry (such as customer service representatives). Occupations into which individuals enter from out of the labor force tend to be lower skill, typically part-time occupations or occupations offering flexibility, as is expected in unretirement; some of these occupations are, surprisingly, quite physically demanding. Occupations most likely to be entered into by previously unemployed workers are similarly low-skill, have low barriers to entry, and are also likely not well paid. These findings underscore concerns, especially in the wake of the Great Recession, for older displaced workers.

When we look at specific occupation-to-occupation transitions, there are no large pipelines from one detailed occupation to another, and especially not between occupations that are not very closely related to one another. Instead, individuals are most likely to move between 
closely-related occupations if they change occupations at all, and are more likely to move “down” than “up” after age 55.

In the second part of our analysis, we look at changes from longest held occupation to several target ages that span Social Security eligibility ages and modal retirement ages. We find occupations that are not workers' career occupations become about as common as workers age as continued employment in their career occupation. That is, we find that likely bridge jobs, unretirement, and encore jobs are about as common as continued career work after age 66. As in our analysis of wave-to-wave occupation changes, in our analysis of transitions from career jobs at later ages, we also find that there are no large pipelines between specific occupations, nor are there any "surprising” occupational transitions that are common. These findings also support other research showing that older workers who leave long-term jobs held for more than 10 years tended to move out of managerial occupations and into sales and service occupations (Johnson and Kawachi, 2007).

Our last analyses also explored changes in earnings associated with occupational changes at older ages. We find that among individuals who change occupations at older ages from the career occupation to another occupation, we are more likely to see earnings decline than increase. These findings support Kawachi and Johnson’s (2007) finding that occupational changes at older ages may be associated with earnings declines. This may reflect strategic decisions on the part of workers who may be willing to trade earnings for work hours flexibility or part-time work.

Lastly, we examined occupations rated by respondents as more physically demanding and stressful to characterize later life transitions. Not surprisingly, career occupations rated as very physically demanding had very high rates of labor for exit by age 66. Interestingly, several 
common stressful jobs had fairly high career retention ( 16-17 percent) at age 66 , and there was very little occupational change even within these more stressful occupations.

Our next step will be to compare these transitions on the basis of work hours flexibility and job stress to understand whether, on balance, these might be transitions that trade flexibility, lower stress, or fewer hours for lower pay. We will also deepen the analyses to include a more nuanced understanding of the changes in work hours associated with transitions to better determine whether the second period job is a bridge job.

In summary, this descriptive work provides clues about useful areas to investigate and adds to our understanding of the trend toward working longer and the alternate routes now being taken to retirement. Ultimately, this program of research will add to our understanding of the trend toward working longer and the alternate routes now being taken to retirement and may inform policy aimed at retaining workers in the labor force to older ages. 


\section{References}

Bound, J., Stinebrickner, T., and Waidmann, T. (2010). Health, economic resources, and the work decisions of older men. Journal of Econometrics, 156(1), 106-129.

Cahill, K. E., Giandrea, M. D., and Quinn, J. (2011). Reentering the labor force after retirement. Monthly Labor Review, 134(6).

Cahill, K., Giandrea, M., and Quinn, J. (2014). The impact of work hours flexibility on career employment, bridge jobs, and the timing of retirement. Bureau of Labor Statistics Working Paper 472.

Cahill, K., Giandrea, M., and Quinn, J. (2015). Retirement patterns and the macroeconomy, 1992-2010: The prevalence and determinants of bridge jobs, phased retirement, and reentry among three recent cohorts of older Americans. Gerontologist, 55(3), 384-403.

Chien, S., Campbell, N., Hayden, O., Hurd, M., Main, M., Mallett, .J, et al. (2015). RAND HRS Data Documentation, Version O. Santa Monica, CA: RAND Center for the Study of Aging.

Gustman, A. L., and Steinmeier, T. L. (2015). Effects of Social Security policies on benefit claiming, retirement and saving. Journal of Public Economics, 129(C), 51-62.

Hurd, M. and Rohwedder, S. (2011). Trends in labor force participation: How much is due to changes in pensions? Journal of Population Ageing, 4(1-2), 81-96.

Insler, M. (2014). The Health Consequences of retirement. Journal of Human Resources, 49(1), 195-233.

Johnson, Richard W. 2004. "Trends in Job Demands Among Older Workers, 1992-2002" Monthly Labor Review 127 (7): 48-56

Johnson, R. and Kawachi, J. (2007). Job changes at older ages: Effects on wages, benefits, and other job attributes, 2007 (CRR Working Paper) 
Johnson, R., Mermin, G., and Ressenger, M. (2007). Employment at older ages and the changing nature of work. AARP Public Policy Institute Report No. 2007-20 Washington, DC: AARP.

Johnson, R. W., Butrica, B. A., and Mommaerts, C. (2010). Work and retirement patterns for the G.I. generation, silent generation, and early boomers: Thirty years of change. (CRR Working Paper No. 2010-8). Boston, MA: Center for Retirement Research at Boston College.

Kail, B. L. and Warner, D. F. (2013). Leaving Retirement: Age-Graded Relative Risks of Transitioning Back to Work or Dying. Population Research and Policy Review 32(2), 159-182.

Maestas, N. (2010). Back to work: Expectations and realizations of work after retirement. Journal of Human Resources, 45(3), 718-748.

McFall, B.H., Sonnega, A., Willis, R.J. and Hudomiet, P. (2015). Occupations and work characteristics: Effects on retirement expectations and timing. Michigan Retirement Research Center WP 2015-331.

Mermin, G. B. T., Johnson, R. W., and Murphy, D. P. (2007). Why do Boomers plan to work longer? The Journals of Gerontology Series B: Psychological Sciences and Social Sciences, 62B(5), s286-s294.

Nolte, M. A., Turf, M., and Servais, M. (2014). Occupation and industry coding in HRS/AHEAD. Retrieved from University of Michigan website: http://hrsonline.isr.umich.edu/sitedocs/userg/dr-021.pdf

Pleau, R. (2010). Gender Differences in Postretirement Employment, Research on Aging, 32, 267-303.

Rohwedder, S., and Willis, R. J. (2010). Mental retirement. The Journal of Economic Perspectives, 24(1), 119-138.

Wang, M., Zhan, Y., Liu, S., and Scultz, K. S. (2008). Antecedents of bridge employment: A longitudinal investigation. Journal of Applied Psychology, 93, 818-830. 
Table 1. 15 most common occupations in the HRS, all workers aged 55+, 1992-2010

\begin{tabular}{|c|c|c|c|c|c|c|c|}
\hline Code & Occupation description & $\begin{array}{c}\text { Obs. } \\
\text { (person x } \\
\text { wave) }\end{array}$ & Individuals & $\begin{array}{c}\% \text { of all } \\
\text { obs. }\end{array}$ & $\begin{array}{l}\% \text { of all } \\
\text { indiv. }\end{array}$ & $\begin{array}{c}\text { Mean } \\
\text { earnings } \\
(2016 \$ / h r)\end{array}$ & $\begin{array}{c}\text { Mean } \\
\text { educ. (yrs) }\end{array}$ \\
\hline 6 & Other managers & 3,803 & 1,723 & 7.6 & 7.3 & $\$ 42.04$ & 13.9 \\
\hline 69 & Other sales and sales related & 2,204 & 1,072 & 4.4 & 4.6 & $\$ 19.65$ & 13.2 \\
\hline 62 & Supervisors and proprietors of sales jobs & 1,629 & 824 & 3.2 & 3.5 & $\$ 26.19$ & 13.1 \\
\hline 72 & Secretaries, Stenographers, and Typists & 1,529 & 641 & 3.0 & 2.7 & $\$ 20.03$ & 13.2 \\
\hline 155 & Truck, delivery, tractor drivers and parking lot attendants & 1,452 & 590 & 2.9 & 2.5 & $\$ 18.84$ & 11.2 \\
\hline 183 & Janitors & 1,429 & 640 & 2.8 & 2.7 & $\$ 14.79$ & 10.5 \\
\hline 187 & Nursing aides, orderlies, and attendants & 1,198 & 574 & 2.4 & 2.4 & $\$ 13.21$ & 11.6 \\
\hline 190 & Child care workers & 985 & 547 & 2.0 & 2.3 & $\$ 9.79$ & 11.2 \\
\hline 81 & Bookkeepers and accounting and auditing clerks & 944 & 441 & 1.9 & 1.9 & $\$ 22.12$ & 13.2 \\
\hline 175 & Private household occupations & 865 & 410 & 1.7 & 1.7 & $\$ 13.12$ & 10.1 \\
\hline 135 & Farm operators and managers & 862 & 305 & 1.7 & 1.3 & $\$ 26.85$ & 12.1 \\
\hline 31 & Primary school teachers & 776 & 320 & 1.5 & 1.4 & $\$ 29.30$ & 16.3 \\
\hline 25 & Registered nurses & 737 & 278 & 1.5 & 1.2 & $\$ 33.51$ & 15.1 \\
\hline 70 & Office supervisors & 690 & 353 & 1.4 & 1.5 & $\$ 23.49$ & 13.3 \\
\hline \multirow[t]{2}{*}{32} & Secondary school teachers & 629 & 249 & 1.3 & 1.1 & $\$ 31.60$ & 16.4 \\
\hline & Total in all 192 occupations & 50,309 & 23,562 & 100 & 100 & $\$ 25.15$ & 12.9 \\
\hline
\end{tabular}


Table 2a. Transitions into occupations, top 15 changing from another occupation at wave t-1 into listed occupation at wave $t$

\begin{tabular}{|c|c|c|c|c|}
\hline Code & Occupation description & $\begin{array}{l}\% \text { changes from } \\
\text { another occupation }\end{array}$ & $\begin{array}{l}\text { \# chg from } \\
\text { another occ. }\end{array}$ & $\begin{array}{l}\text { Total in } \\
\text { occ at } \\
\text { wave } t\end{array}$ \\
\hline 5 & Managers of properties and real estate & $50.3 \%$ & 80 & 159 \\
\hline 117 & Supervisors of construction work & $45.4 \%$ & 166 & 366 \\
\hline 164 & Construction helpers and laborers, surveyor helpers & $40.1 \%$ & 136 & 339 \\
\hline 94 & Customer service reps, investigators and adjusters, except insurance & $38.7 \%$ & 87 & 225 \\
\hline 139 & Timber, logging, and forestry workers & $37.8 \%$ & 17 & 45 \\
\hline 62 & Supervisors and proprietors of sales jobs & $33.4 \%$ & 446 & 1,334 \\
\hline 111 & Telecom and line installers and repairers & $33.3 \%$ & 9 & 27 \\
\hline 119 & Carpenters & $32.6 \%$ & 95 & 291 \\
\hline 97 & General office clerks & $31.8 \%$ & 106 & 333 \\
\hline 122 & Painters, construction and maintenance & $31.7 \%$ & 32 & 101 \\
\hline 92 & Material recording, scheduling, production, planning, and expediting clerks & $31.0 \%$ & 35 & 113 \\
\hline 114 & Other electronic or electrical equipment repairers & $30.4 \%$ & 17 & 56 \\
\hline 51 & Athletes, sports instructors, officials and announcers & $29.8 \%$ & 14 & 47 \\
\hline 81 & Bookkeepers and accounting and auditing clerks & $26.8 \%$ & 221 & 825 \\
\hline 34 & Teachers, n.e.c. & $26.8 \%$ & 84 & 314 \\
\hline
\end{tabular}


Table $\mathbf{2 b}$. Transitions into occupations, top 15 remaining in same occupation in wave $t$ as wave $t-1$

\begin{tabular}{|c|c|c|c|c|}
\hline Code & Occupation description & $\begin{array}{l}\% \text { continuing from } \\
\text { same occupation }\end{array}$ & $\begin{array}{l}\text { \# cont. from } \\
\text { same occ. }\end{array}$ & $\begin{array}{c}\text { Total in } \\
\text { occ at } \\
\text { wave } t\end{array}$ \\
\hline 32 & Secondary school teachers & $81.9 \%$ & 439 & 536 \\
\hline 53 & Radiologic tech specialists & $81.5 \%$ & 22 & 27 \\
\hline 31 & Primary school teachers & $81.5 \%$ & 528 & 648 \\
\hline 157 & Bus drivers & $80.2 \%$ & 337 & 420 \\
\hline 127 & Precision metal working occupations & $79.5 \%$ & 163 & 205 \\
\hline 41 & Clergy and religious workers & $79.4 \%$ & 363 & 457 \\
\hline 153 & Production inspectors, testers, samplers, and weighers & $78.7 \%$ & 218 & 277 \\
\hline 100 & Teacher assistants & $78.6 \%$ & 309 & 393 \\
\hline 72 & Secretaries, Stenographers, and Typists & $77.3 \%$ & 1006 & 1301 \\
\hline 179 & Other cooks & $75.2 \%$ & 346 & 460 \\
\hline 155 & Truck, delivery, tractor drivers and parking lot attendants & $74.8 \%$ & 886 & 1184 \\
\hline 141 & Metal working and plastic working machine operators & $73.1 \%$ & 87 & 119 \\
\hline 70 & Office supervisors & $72.5 \%$ & 403 & 556 \\
\hline 21 & Life scientists & $71.7 \%$ & 33 & 46 \\
\hline 135 & Farm operators and managers & $70.8 \%$ & 516 & 729 \\
\hline
\end{tabular}


Table 2c. Transitions into occupations, top 15 entering to occupation at wave $t$ from out of labor force in wave t-1

\begin{tabular}{|c|c|c|c|c|}
\hline Code & Occupation description & $\begin{array}{c}\% \text { enters LF into } \\
\text { occ }\end{array}$ & $\begin{array}{c}\text { \# enters LF into } \\
\text { occ }\end{array}$ & $\begin{array}{c}\text { Total in } \\
\text { occ at } \\
\text { wave } t\end{array}$ \\
\hline 190 & Child care workers & $21.9 \%$ & 180 & 823 \\
\hline 158 & Taxi cab drivers and chauffeurs & $20.1 \%$ & 57 & 284 \\
\hline 137 & Gardeners and groundskeepers & $19.6 \%$ & 75 & 383 \\
\hline 86 & Mail clerks, outside of post office & $18.8 \%$ & 9 & 48 \\
\hline 139 & Timber, logging, and forestry workers & $17.8 \%$ & 8 & 45 \\
\hline 51 & Athletes, sports instructors, officials and announcers & $17.0 \%$ & 8 & 47 \\
\hline 175 & Private household occupations & $16.1 \%$ & 115 & 715 \\
\hline 189 & Recreation facility attendants & $15.2 \%$ & 19 & 125 \\
\hline 164 & Construction helpers and laborers, surveyor helpers & $13.0 \%$ & 44 & 339 \\
\hline 119 & Carpenters & $12.4 \%$ & 36 & 291 \\
\hline 173 & Guards, watchmen, doorkeepers & $11.9 \%$ & 54 & 452 \\
\hline 75 & Information clerks, nec & $11.8 \%$ & 59 & 498 \\
\hline 187 & Nursing aides, orderlies, and attendants & $11.7 \%$ & 116 & 992 \\
\hline 182 & Misc food prep workers & $11.4 \%$ & 28 & 246 \\
\hline 69 & Other sales and sales related & $11.4 \%$ & 215 & 1889 \\
\hline
\end{tabular}


Table 2d. Transitions into occupations, top 15 entering occupation at wave $t$ from unemployed or on leave in wave t-1

\begin{tabular}{|c|c|c|c|c|}
\hline Code & Occupation description & $\begin{array}{c}\% \text { finds job in occ } \\
\text { from not working } \\
\text { but in LF }\end{array}$ & $\begin{array}{c}\text { \# finds job from } \\
\text { not working but in } \\
\text { LF }\end{array}$ & $\begin{array}{l}\text { Total in } \\
\text { occ at } \\
\text { wave t }\end{array}$ \\
\hline 122 & Painters, construction and maintenance & $9.9 \%$ & 10 & 101 \\
\hline 141 & Metal working and plastic working machine operators & $6.7 \%$ & 8 & 119 \\
\hline 119 & Carpenters & $4.1 \%$ & 12 & 291 \\
\hline 164 & Construction helpers and laborers, surveyor helpers & $3.5 \%$ & 12 & 339 \\
\hline 190 & Child care workers & $3.4 \%$ & 28 & 823 \\
\hline 187 & Nursing aides, orderlies, and attendants & $3.3 \%$ & 33 & 992 \\
\hline 173 & Guards, watchmen, doorkeepers & $3.3 \%$ & 15 & 452 \\
\hline 75 & Information clerks, nec & $3.2 \%$ & 16 & 498 \\
\hline 158 & Taxi cab drivers and chauffeurs & $3.2 \%$ & 9 & 284 \\
\hline 137 & Gardeners and groundskeepers & $3.1 \%$ & 12 & 383 \\
\hline 182 & Misc food prep workers & $2.8 \%$ & 7 & 246 \\
\hline 67 & Cashiers & $2.8 \%$ & 13 & 462 \\
\hline 94 & Customer service reps, investigators and adjusters, except insurance & $2.7 \%$ & 6 & 225 \\
\hline 136 & Farm occupations, except managerial & $2.6 \%$ & 8 & 304 \\
\hline 2 & Human resources, marketing, advertising, public relation managers & $2.6 \%$ & 9 & 347 \\
\hline
\end{tabular}


Table 3. Transitions between occupations between waves (excludes "not in labor force" and "other" occupations) (workers aged 55+)

$\begin{array}{ccccc}\begin{array}{c}\text { Code at } \\ \text { wave } t-1\end{array} & \text { Occupation description at wave } t-1 & \begin{array}{l}\text { Code at } \\ \text { wave } t\end{array} & \text { Occupation description at wave } t & \text { Count } \\ \text { transition/ }\end{array}$

\begin{tabular}{|c|c|c|c|c|c|}
\hline 175 & Private household occupations & 183 & Janitors & 38 & $2.7 \%$ \\
\hline 183 & Janitors & 175 & Private household occupations & 38 & $4.4 \%$ \\
\hline 190 & Child care workers & 187 & Nursing aides, orderlies, and attendants & 37 & $3.1 \%$ \\
\hline 135 & Farm operators and managers & 136 & Farm occupations, except managerial & 30 & $8.3 \%$ \\
\hline 97 & General office clerks & 72 & Secretaries, Stenographers, and Typists & 27 & $1.8 \%$ \\
\hline 136 & Farm occupations, except managerial & 135 & $\begin{array}{l}\text { Farm operators and managers } \\
\text { Construction helpers and laborers, surveyor }\end{array}$ & 26 & $3.0 \%$ \\
\hline 119 & Carpenters & 164 & $\begin{array}{l}\text { helpers } \\
\text { Bookkeepers and accounting and auditing }\end{array}$ & 23 & $5.6 \%$ \\
\hline 72 & Secretaries, Stenographers, and Typists & 81 & clerks & 23 & $2.4 \%$ \\
\hline 19 & Mathematical and Computer Scientists & 60 & $\begin{array}{l}\text { Computer programmers, support specialists } \\
\text { and administrators }\end{array}$ & 22 & 13.99 \\
\hline 31 & Primary school teachers & 32 & Secondary school teachers & 22 & $3.5 \%$ \\
\hline 70 & Office supervisors & 72 & Secretaries, Stenographers, and Typists & 21 & $1.4 \%$ \\
\hline 119 & $\begin{array}{l}\text { Carpenters } \\
\text { Bookkeepers and accounting and auditing }\end{array}$ & 117 & Supervisors of construction work & 21 & $4.7 \%$ \\
\hline 81 & clerks & 72 & Secretaries, Stenographers, and Typists & 20 & $1.3 \%$ \\
\hline 75 & Information clerks, nec & 72 & Secretaries, Stenographers, and Typists & 20 & $4.7 \%$ \\
\hline 175 & Private household occupations & 187 & $\begin{array}{l}\text { Nursing aides, orderlies, and attendants } \\
\text { Bookkeepers and accounting and auditing }\end{array}$ & 20 & $1.7 \%$ \\
\hline 7 & Accountants and auditors & 81 & clerks & 20 & $2.1 \%$ \\
\hline 32 & Secondary school teachers & 31 & Primary school teachers & 20 & $2.6 \%$ \\
\hline 175 & $\begin{array}{l}\text { Private household occupations } \\
\text { Bookkeepers and accounting and auditing }\end{array}$ & 190 & Child care workers & 19 & $1.9 \%$ \\
\hline 81 & clerks & 7 & Accountants and auditors & 17 & $4.4 \%$ \\
\hline 72 & Secretaries, Stenographers, and Typists & 97 & General office clerks & 17 & $4.3 \%$ \\
\hline 187 & Nursing aides, orderlies, and attendants & 190 & Child care workers & 17 & $1.7 \%$ \\
\hline
\end{tabular}


Table 4. Transitions at older ages relative to longest-held occupation as of age 55

\begin{tabular}{|c|c|c|}
\hline & Count & Percent \\
\hline \multicolumn{3}{|l|}{ Age 62} \\
\hline No longer in labor force & 4,330 & $57.4 \%$ \\
\hline In same occupation as longest-held job as of age 55 & 1,924 & $25.5 \%$ \\
\hline In different occupation relative to longest-held job as of age 55 & 1294 & $17.1 \%$ \\
\hline Total & 7,548 & $100 \%$ \\
\hline \multicolumn{3}{|l|}{ Age 66} \\
\hline No longer in labor force & 4,207 & $73.4 \%$ \\
\hline In same occupation as longest-held job as of age 55 & 768 & $13.4 \%$ \\
\hline In different occupation relative to longest-held job as of age 55 & 754 & $13.2 \%$ \\
\hline Total & 5,729 & $100 \%$ \\
\hline \multicolumn{3}{|l|}{ Age 68} \\
\hline No longer in labor force & 3,754 & $78.5 \%$ \\
\hline In same occupation as longest-held job as of age 55 & 527 & $11.0 \%$ \\
\hline In different occupation relative to longest-held job as of age 55 & 499 & $10.4 \%$ \\
\hline Total & 4,780 & $100 \%$ \\
\hline \multicolumn{3}{|l|}{ Age 70} \\
\hline No longer in labor force & 3,214 & $83.3 \%$ \\
\hline In same occupation as longest-held job as of age 55 & 323 & $8.4 \%$ \\
\hline In different occupation relative to longest-held job as of age 55 & 320 & $8.3 \%$ \\
\hline Total & 3,857 & $100 \%$ \\
\hline
\end{tabular}


Table 5. Transitions from longest-held occupation at age 55 to different occupation at age $62,66,68$ and 70

\begin{tabular}{|c|c|c|c|c|}
\hline $\begin{array}{l}\text { Code at } \\
\text { wave } t-1\end{array}$ & Occupation description at wave $\mathrm{t}-1$ & $\begin{array}{l}\text { Code at } \\
\text { wave } t\end{array}$ & Occupation description at wave $t$ & Count \\
\hline \multicolumn{5}{|c|}{ Longest-held occupation at age 55 to different occupation at age 62} \\
\hline 72 & Secretaries, Stenographers, and Typists & 97 & General office clerks & 12 \\
\hline 175 & Private household occupations & 183 & Janitors & 11 \\
\hline 72 & Secretaries, Stenographers, and Typists & 75 & Information clerks, nec & 9 \\
\hline 70 & Office supervisors & 72 & Secretaries, Stenographers, and Typists & 7 \\
\hline 72 & Secretaries, Stenographers, and Typists & 81 & $\begin{array}{l}\text { Bookkeepers and accounting and auditing } \\
\text { clerks }\end{array}$ & 7 \\
\hline 81 & $\begin{array}{l}\text { Bookkeepers and accounting and auditing } \\
\text { clerks }\end{array}$ & 72 & Secretaries, Stenographers, and Typists & 7 \\
\hline 175 & Private household occupations & 187 & Nursing aides, orderlies, and attendants & 7 \\
\hline 190 & Child care workers & 187 & Nursing aides, orderlies, and attendants & 7 \\
\hline 31 & Primary school teachers & 190 & Child care workers & 6 \\
\hline 32 & Secondary school teachers & 34 & Teachers, n.e.c. & 6 \\
\hline 183 & Janitors & 175 & Private household occupations & 6 \\
\hline 31 & Primary school teachers & 29 & Postsecondary teachers & 5 \\
\hline 31 & Primary school teachers & 32 & Secondary school teachers & 5 \\
\hline 62 & Supervisors and proprietors of sales jobs & 63 & Insurance sales occupations & 5 \\
\hline 72 & Secretaries, Stenographers, and Typists & 67 & Cashiers & 5 \\
\hline 136 & Farm occupations, except managerial & 135 & Farm operators and managers & 5 \\
\hline 155 & $\begin{array}{l}\text { Truck, delivery, tractor drivers and parking lot } \\
\text { attendants }\end{array}$ & 183 & Janitors & 5 \\
\hline 175 & Private household occupations & 190 & Child care workers & 5 \\
\hline
\end{tabular}

Cont. on next page. 
Table 5., continued

\begin{tabular}{|c|c|c|c|c|}
\hline \multicolumn{5}{|c|}{ Longest-held occupation at age 55 to different occupation at age 66} \\
\hline 70 & Office supervisors & 72 & Secretaries, Stenographers, and Typists & 9 \\
\hline 81 & Bookkeepers and accounting and auditing clerks & 72 & Secretaries, Stenographers, and Typists & 6 \\
\hline 175 & Private household occupations & 183 & Janitors & 6 \\
\hline 175 & Private household occupations & 187 & Nursing aides, orderlies, and attendants & 6 \\
\hline 1 & Financial managers & 81 & $\begin{array}{l}\text { Bookkeepers and accounting and auditing } \\
\text { clerks }\end{array}$ & 5 \\
\hline 32 & Secondary school teachers & 31 & Primary school teachers & 5 \\
\hline 72 & Secretaries, Stenographers, and Typists & 81 & $\begin{array}{l}\text { Bookkeepers and accounting and auditing } \\
\text { clerks }\end{array}$ & 5 \\
\hline \multicolumn{5}{|c|}{ Longest-held occupation at age 55 to different occupation at age 68} \\
\hline 72 & Secretaries, Stenographers, and Typists & 75 & Information clerks, nec & 7 \\
\hline \multicolumn{5}{|c|}{ Longest-held occupation at age 55 to different occupation at age $\mathbf{7 0}$} \\
\hline 72 & Secretaries, Stenographers, and Typists & 75 & Information clerks, nec & 7 \\
\hline
\end{tabular}


Table 6. Transitions from longest-held occupation at age 55 to occupation at older ages, with earnings changes

\begin{tabular}{|c|c|c|c|c|c|}
\hline & Count & Percent & & Count & Percent \\
\hline \multicolumn{3}{|c|}{ Longest-held occupation at 55 to occupation at $62(\mathrm{~N}=7,548)$} & \multicolumn{3}{|c|}{ Longest-held occupation at 55 to occupation at $68(\mathrm{~N}=4,780)$} \\
\hline Same Job & 1,924 & $25.5 \%$ & Same Job & 527 & $11.0 \%$ \\
\hline Changes Career - Lateral (<10\% either way) & 331 & $4.4 \%$ & Changes Career - Lateral ( $<10 \%$ either way) & 81 & $1.7 \%$ \\
\hline Changes Career - Down 10-25\% & 149 & $2.0 \%$ & Changes Career - Down 10-25\% & 51 & $1.1 \%$ \\
\hline Changes Career - Down 26-50\% & 157 & $2.1 \%$ & Changes Career - Down 26-50\% & 83 & $1.7 \%$ \\
\hline \multicolumn{3}{|c|}{ Longest-held occupation at 55 to occupation at $66(\mathrm{~N}=5,729)$} & \multicolumn{3}{|c|}{ Longest-held occupation at 55 to occupation at $70(\mathrm{~N}=3,857)$} \\
\hline Leaves Labor Force & 4,207 & $73.4 \%$ & Leaves Labor Force & 3214 & $83.3 \%$ \\
\hline Same Job & 768 & $13.4 \%$ & Same Job & 323 & $8.4 \%$ \\
\hline Changes Career - Up > 10\% & 260 & $4.5 \%$ & Changes Career - Up > 10\% & 107 & $2.8 \%$ \\
\hline Changes Career - Lateral (< $10 \%$ either way) & 139 & $2.4 \%$ & Changes Career - Lateral ( $<10 \%$ either way) & 45 & $1.2 \%$ \\
\hline Changes Career - Down 10-25\% & 82 & $1.4 \%$ & Changes Career - Down 10-25\% & 40 & $1.0 \%$ \\
\hline
\end{tabular}


Table 7. Transitions between longest-held occupation at age 55 and age 66

\begin{tabular}{|c|c|c|c|c|c|c|c|c|c|}
\hline \multirow[b]{2}{*}{ Code } & \multirow[b]{2}{*}{ Longest-held occupation } & \multirow[b]{2}{*}{$\begin{array}{c}\text { \% exit } \\
\text { LF }\end{array}$} & \multirow{2}{*}{$\begin{array}{c}\% \\
\text { same } \\
\text { occ } \\
\end{array}$} & \multicolumn{5}{|c|}{ \% different occ, by earnings change } & \multirow{2}{*}{$\begin{array}{c}\mathbf{N} \text { (excl. } \\
\text { suppressed } \\
\text { cells) }\end{array}$} \\
\hline & & & & $\begin{array}{c}\text { Up } \\
10 \%+\end{array}$ & $\begin{array}{c}\text { No } \\
\text { change }\end{array}$ & $\begin{array}{c}\text { Down } \\
10-25 \% \\
\end{array}$ & $\begin{array}{c}\text { Down } \\
26-50 \%\end{array}$ & $\begin{array}{l}\text { Down } \\
50 \%+\end{array}$ & \\
\hline $\mathrm{n} / \mathrm{a}$ & Overall & $73 \%$ & $13 \%$ & $5 \%$ & $2 \%$ & $1 \%$ & $2 \%$ & $3 \%$ & 5,729 \\
\hline \multicolumn{10}{|c|}{ Common physically-demanding longest-held occupation at age 55 to status at age 66} \\
\hline 136 & Farm occupations, except managerial & $69 \%$ & $31 \%$ & $*$ & * & * & $0 \%$ & $0 \%$ & 51 \\
\hline 144 & Textile sewing machine operators & $89 \%$ & $5 \%$ & $5 \%$ & $*$ & $0 \%$ & $*$ & $0 \%$ & 57 \\
\hline 150 & Other machine operators, assorted materials & $97 \%$ & $3 \%$ & $*$ & $*$ & $*$ & $*$ & $*$ & 87 \\
\hline 152 & Assemblers and fabricators & $91 \%$ & $2 \%$ & $*$ & $8 \%$ & $*$ & $*$ & $*$ & 65 \\
\hline 168 & Other freight, stock, and material handlers & $87 \%$ & $7 \%$ & $*$ & $*$ & $0 \%$ & $*$ & $7 \%$ & 61 \\
\hline 175 & Private household occupations & $85 \%$ & $13 \%$ & $*$ & $0 \%$ & $3 \%$ & * & $*$ & 120 \\
\hline 187 & Nursing aides, orderlies, and attendants & $85 \%$ & $13 \%$ & * & $2 \%$ & $*$ & $*$ & $0 \%$ & 126 \\
\hline \multicolumn{10}{|c|}{ Common high-stress longest-held occupation at age 55 to status at age 66} \\
\hline 6 & Other managers & $65 \%$ & $17 \%$ & $7 \%$ & $2 \%$ & $1 \%$ & $4 \%$ & $4 \%$ & 462 \\
\hline 25 & Registered nurses & $81 \%$ & $16 \%$ & $4 \%$ & * & $0 \%$ & * & * & 77 \\
\hline 31 & Primary school teachers & $80 \%$ & $16 \%$ & $*$ & $2 \%$ & $*$ & $2 \%$ & $*$ & 140 \\
\hline 32 & Secondary school teachers & $70 \%$ & $17 \%$ & $6 \%$ & $3 \%$ & $*$ & $*$ & $4 \%$ & 100 \\
\hline 70 & Office supervisors & $81 \%$ & $8 \%$ & $11 \%$ & $*$ & $*$ & $*$ & $*$ & 112 \\
\hline 126 & Production supervisors or foremen & $82 \%$ & $5 \%$ & $7 \%$ & $*$ & $*$ & $*$ & $6 \%$ & 85 \\
\hline
\end{tabular}




\section{Appendix A - CPS Data Work}

\section{Data}

Microdata from the Current Population Study (CPS) were accessed using the Integrated Public Use Microdata Series (Flood et. al., 2015). Data was provided from Version 4.0 of the IPUMS-CPS database, and was accessed on May 10, 2016.

We use all basic monthly CPS surveys from January 1992 to December 2012 (252 survey periods). These years correspond with the survey periods of the Health and Retirement Study data used in this project. The CPS is administered by the Census Bureau, and respondents are interviewed up to eight times. Households are interviewed in a 4-8-4 schedule, where they are interviewed for four consecutive months, not interviewed for eight months, and then interviewed for four more consecutive months (CPS Technical Paper 66).

The CPS collects respondent-level data for all respondents within a household. Questions apply to a respondent's previous week. Data are collected on the respondent's current labor force status, hours worked, wage and occupation. Standard demographic information is also collected.

We keep all responses from respondents 50 years of age or older, giving us 1,783,644 respondents and a total of 9,980,510 survey responses. These individuals represent a total of 1,190,690 households. Table 1 shows the number of times a respondent used in this analysis was surveyed in the CPS. Respondents or households can drop out of the survey for a number of reasons, including moving, though the CPS Technical Appendix notes that the fifth period (after the eight months not interviewed) sees the highest proportion of exit. 
Table 1: Number of surveys per respondent 50+, 1992-2012

\begin{tabular}{|r|c|c|c|}
\hline Time in CPS & Freq. & Percent & Cum. \\
\hline $\mathbf{1}$ & 198,905 & 11.15 & 11.15 \\
\hline $\mathbf{2}$ & 76,365 & 4.28 & 15.43 \\
\hline $\mathbf{3}$ & 87,270 & 4.89 & 20.33 \\
\hline $\mathbf{4}$ & 334,640 & 18.76 & 39.09 \\
\hline $\mathbf{5}$ & 52,183 & 2.93 & 42.01 \\
\hline $\mathbf{6}$ & 63,412 & 3.56 & 45.57 \\
\hline $\mathbf{7}$ & 126,604 & 7.10 & 52.67 \\
\hline $\mathbf{8}$ & 844,265 & 47.33 & 100.00 \\
\hline Total & $1,783,644$ & 100.00 & \\
\hline
\end{tabular}

\section{Data Processing}

This section describes the data processing done on the IPUMS-CPS data. Section 2.1 describes the process used to create an hourly wage variable. Section 2.2 describes the creation of the years of education variable. Section 2.3 describes how the occupation codes were created.

\subsection{Earnings Data}

In order to construct an hourly wage variable, we first use data from the IPUMS-CPS variable hourwage (for more information on when wage questions are asked in the survey, see Section 3). This is a variable for hourly wages for workers who reported that they were paid an hourly wage (paidhour $=2$ ). hourwage is top coded at $\$ 99.97$, though this does not occur in this dataset. The original hourwage variable has data for 489,273 responses. Respondents are told to report earnings before taxes or other deductions.

Workers who report that they are not paid hourly (paidhour $=1$ ) have the opportunity to report weekly earnings, held in the IPUMS-CPS variable earnweek. earnweek is top coded at \$1,923 until 1997, and at \$2,885 from 1998 to 2012.

Additionally, the variable uhrswork1 holds average hours worked per week information. This contains values between 0-99, the last being an indicator for Hours vary. For workers who 
report that they are salaried, we impute the value of 40 if a value of more than 40 or Hours vary was reported. Then, for workers who have no hourly wage reported, but do have information for earnweek and uhrswork1, we impute earnweek divided by uhrswork1 as the hourly wage.

Wage data is then transformed into 2016 dollars using the CPI-U index (http://data.bls.gov/cgi-bin/cpicalc.pl). Figure 1 shows the distribution of hourly wages in the dataset. After imputation, we have hourly wage data for 646,298 responses.

Figure 1: Hourly Wages in CPS data, 2016 Dollars

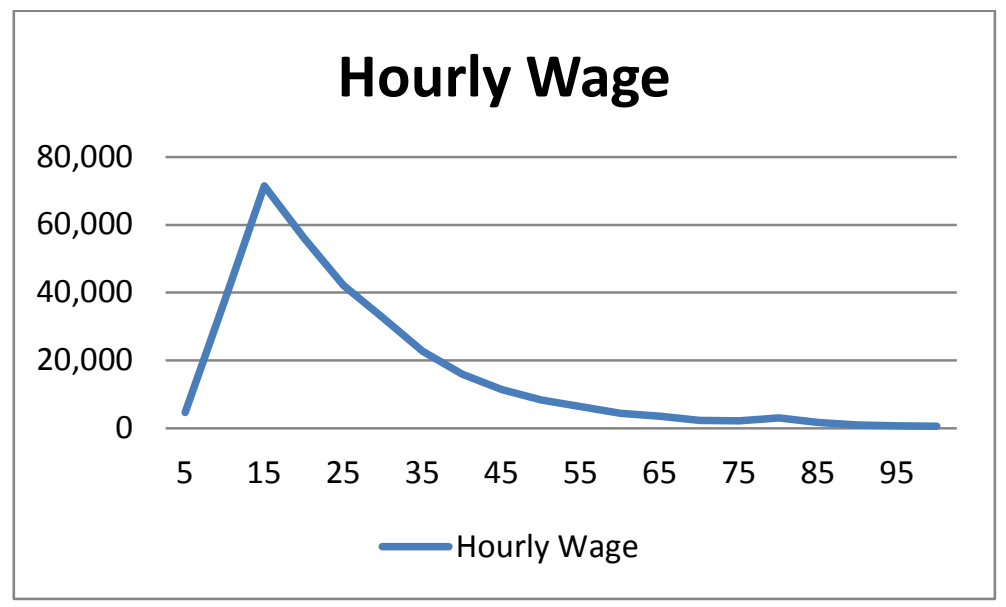

\subsection{Education Data}

The IPUMS-CPS variable educ contains education information in categorical terms. We create a variable educ_years that recodes this information into years of education. Table 2 shows the recoding scheme used.

For respondents who indicated that they were Lawyers, Physicians, or Dentists and responded to educ with Doctorate Degree we assumed that they were referring to a JD, MD, or DDS/DMD respectively. In these cases, we imputed the value 19 rather than 22. 
Table 2: educ to educ_years recode

\begin{tabular}{c|c} 
educ & educ_years \\
\hline No School / Preschool & 0 \\
$1^{\text {st }}-4^{\text {th }}$ Grade & 4 \\
$5^{\text {th }}-6^{\text {th }}$ Grade & 6 \\
$7^{\text {th }}-8^{\text {th }}$ Grade & 8 \\
$9^{\text {th }}$ Grade & 9 \\
$10^{\text {th }}$ Grade & 10 \\
$11^{\text {th }}$ Grade & 11 \\
$12^{\text {th }}$ Grade, no Diploma & 12 \\
HS Diploma or Equivalent & 12 \\
Some College, no Degree & 13 \\
Associates Degree, Occupational & 14 \\
Associates Degree, Academic & 14 \\
Bachelor's Degree & 16 \\
Master's Degree & 17 \\
Professional Degree & 19 \\
Doctorate Degree & 22
\end{tabular}

\subsection{Occupation Codes}

In the CPS, respondents provide detailed occupation information. This information is masked into the census occupational classifications. The IPUMS-CPS variable occ holds the census occupation codes, with about 1,000 different occupation codes. Census occupation codes changed in 2003, and again in 2011. In order to have a consistent occupation code over the period from 1992-2012, and to have an occupation code that is comparable to HRS codes, we utilize coding developed by Peter Hudomiet (Sonnega et al., 2015) to narrow down the grouping into 192 occupation types.

Occupation information exists for 4,644,099 responses in the survey. Missing values for this variable are primarily due to many respondents in the survey being retired. 


\section{Dataset Creation}

We create a dataset that allows for the comparison of earnings and occupation of the same respondent at different times. Because of the form of the CPS survey, however, this limits us to two survey periods per respondent. Specifically, the Outgoing Rotation Group/Earner Study questions that collect the wage information are only asked at most twice per respondent. The description of the Earner Study notes that these questions are supposed to be asked in survey four and eight only (this would be one year apart) to respondents who are currently employed as wage or salaried workers.

We do find some respondents who are asked these questions in periods other than surveys four and eight, but in these cases the survey design is preserved in that i) these respondents are still only asked wage questions at most two times total, and ii) the times the respondent is asked these questions is always separated by one year (i.e. periods one and five, two and six, or three and seven).

Thus, in order to create a dataset that allows for comparison of earnings and occupation of the same respondent at different times, we keep the two survey responses by the respondent during the periods that they answered earnings questions. For the most part, this is surveys 4 and 8, but we do keep respondents who answered these questions in surveys 1 and 5, etc.

In cases where earnings data exists in only one survey, we keep the respondent if they report that they were not in the labor force in the corresponding survey one year after. For example, if a respondent reported their earnings in the $4^{\text {th }}$ survey, we keep them if they report that they are out of the labor force in the $8^{\text {th }}$ survey. This also works for labor force reentry, so if a respondent reports earnings in the $6^{\text {th }}$ survey, we keep them if they report that they are out of the labor force in the $2^{\text {nd }}$ survey. 
Thus, we create a dataset with 350,873 respondents. Gender is representative of the U.S. in this sample (48.92 percent male). Whites are over-represented in the sample (86.47 percent white).

\section{References}

Sarah Flood, Miriam King, Steven Ruggles, and J. Robert Warren. Integrated Public Use Microdata Series, Current Population Survey: Version 4.0. [Machine-readable database]. Minneapolis: University of Minnesota, 2015.

Design and Methodology, Current Population Survey, Technical Paper 66, U.S. Department of Labor and U.S. Department of Commerce. October 2006

BLS Inflation Calculator, http://data.bls.gov/cgi-bin/cpicalc.pl, Bureau of Labor Statistics, accessed May 12, 2016 


\section{Appendix B - Comparison of CPS and HRS}

Occupations. For those who are working, many occupation rates are similar in the CPS and HRS. Managers are by far the most prevalent occupation in each sample. Other Managers represent 8.8 percent (7.2 percent) of respondents in the CPS (HRS), while the next category represents 4.0 percent (4.0 percent). Past this, other top jobs are represented in both groups. Rank changes slightly, but Other Managers, Other Sales, Supervisors, Secretaries, Truck Drivers, Farm Operators, and Janitors make up the top seven of each group. The top 10 of each group are identical less one position (RNs in CPS, Bookkeepers in HRS).

Throughout the middle of the distribution, positions tend to take similar percentages of the working population. This trend even holds well for the bottom group of jobs, where we tend to see very few instances in the HRS. The bottom occupations (Military, Fishers, Water Transport, Drywall installers, etc.) have similar rates despite the potential for larger sampling errors.

Earnings. Findings for earnings are similar as those for occupations, but more dispersed. At the top, Physicians, Dentists, Lawyers, and Pilots are seen at the top of each group. However, in the HRS, the top earning occupations also include some groups that have highly variable earnings and low participation rates. This includes occupations like Military, Actors, and Athletes that are in the top 10 earning occupations in the HRS sample.

Even controlling for these small groups though, there is still a certain amount of dispersion in the rankings. The top 15 earning occupations in the CPS are contained in the top 34 occupations in the HRS, a relatively large spread.

However, for the majority of the occupations, excluding those with very few HRS observations, mean earning rates do tend to get very close. In addition, in both cases occupation 
rankings follow similar patterns. At the top of each ranking, we see more specialized occupations, while the bottom group contains almost entirely service industry jobs and labor jobs. At the very bottom of each, we see tip jobs (Waiters, Bartenders, Waiters Assistant) as well as other kitchen jobs.

Education. Education comparisons are less dispersed than earnings. The Top 10 of each contains Lawyers, Physicians, Other health, Postsecondary Teachers, Psychologists, Dentists, Physical Scientists, and Life Scientist. In addition, low education jobs are almost the same in each. Manual labor jobs are seen in the bottom of the distribution for both the CPS and the HRS, with similar mean years of education.

One difference in education is the median years of education of low education workers. In the CPS, there is no category where the median education is below 12 . However, in the HRS there are 9 categories with 10-11.5 years of education. 